Provided for non-commercial research and education use. Not for reproduction, distribution or commercial use.

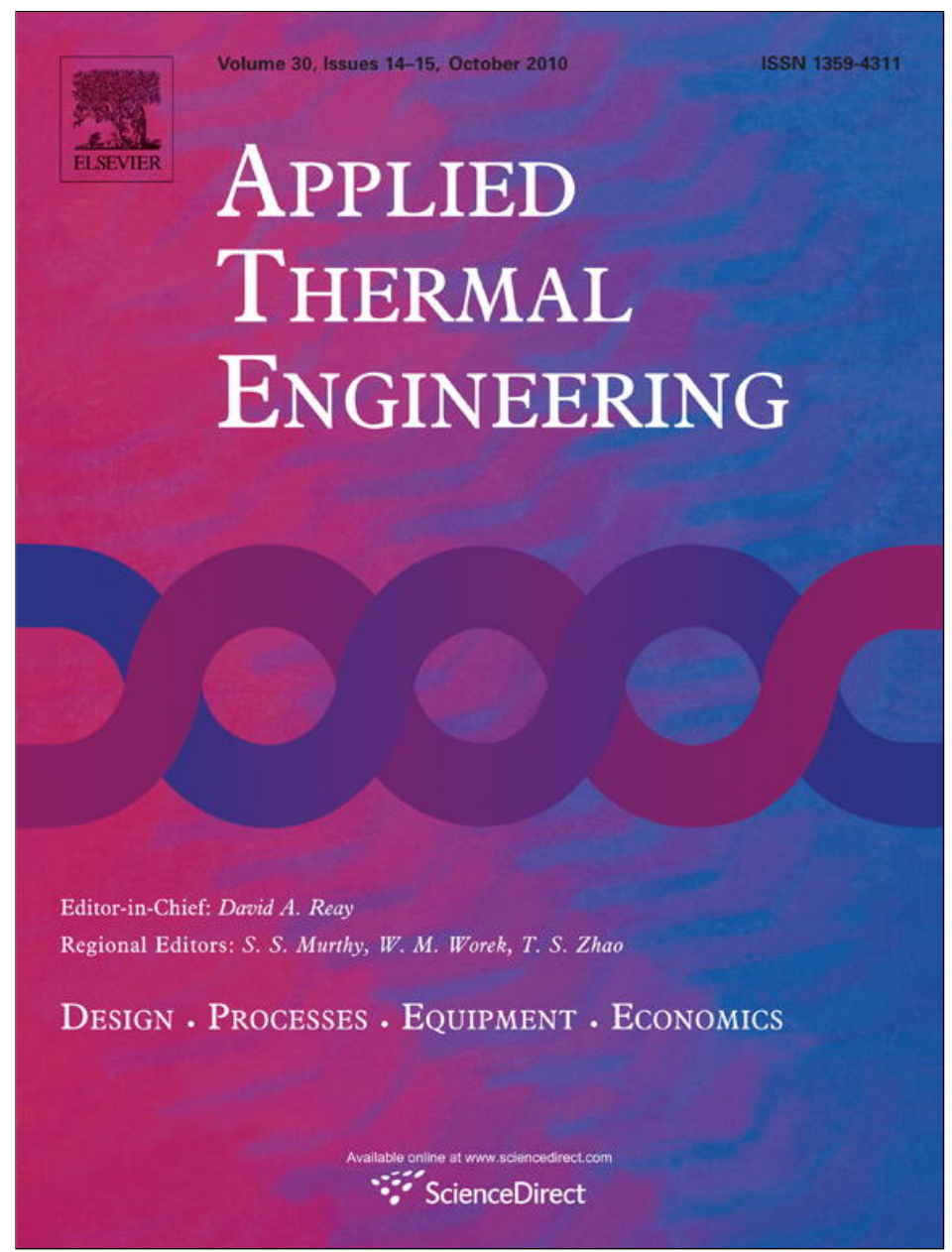

This article appeared in a journal published by Elsevier. The attached copy is furnished to the author for internal non-commercial research and education use, including for instruction at the authors institution and sharing with colleagues.

Other uses, including reproduction and distribution, or selling or licensing copies, or posting to personal, institutional or third party websites are prohibited.

In most cases authors are permitted to post their version of the article (e.g. in Word or Tex form) to their personal website or institutional repository. Authors requiring further information regarding Elsevier's archiving and manuscript policies are encouraged to visit:

http://www.elsevier.com/copyright 


\title{
Optimal control and performance test of solar-assisted cooling system
}

\author{
B.J. Huang ${ }^{\mathrm{a}, *}$, C.W. Yen ${ }^{\text {a }}$, J.H. Wu ${ }^{\text {a }}$, J.H. Liu ${ }^{\text {a }}$, H.Y. Hsu ${ }^{\text {a }}$, V.O. Petrenko ${ }^{\text {a }}$, J.M. Chang ${ }^{b}$, C.W. Lu ${ }^{b}$ \\ ${ }^{a}$ Department of Mechanical Engineering, National Taiwan University, Taipei 106, Taiwan \\ ${ }^{\mathrm{b}}$ Department of Refrigeration, Air Conditioning and Energy Engineering, National Chin-Yi University of Technology, Taichung, Taiwan
}

\section{A R T I C L E I N F O}

Article history:

Received 15 April 2010

Accepted 2 June 2010

Available online 19 June 2010

\section{Keywords:}

Solar energy

Ejector system

Ejector cooling

Solar cooling

\begin{abstract}
A B S T R A C T
The solar-assisted cooling system (SACH) was developed in the present study. The ejector cooling system (ECS) is driven by solar heat and connected in parallel with an inverter-type air conditioner $(A / C)$. The cooling load can be supplied by the ECS when solar energy is available and the input power of the A/C can be reduced. In variable weather, the ECS will probably operate at off-design condition of ejector and the cooling capability of the ECS can be lost completely. In order to make the ejector operate at critical or non-critical double-choking condition to obtain a better performance, an electronic expansion valve was installed in the suction line of the ejector to regulate the opening of the expansion valve to control the evaporator temperature. This will make the $\mathrm{SACH}$ always produce cooling effect even at lower solar radiation periods while the ejector performs at off-design conditions. The energy saving of $A / C$ is experimentally shown $50-70 \%$ due to the cooling performance of ECS. The long-term performance test results show that the daily energy saving is around $30-70 \%$ as compared to the energy consumption of $\mathrm{A} / \mathrm{C}$ alone (without solar-driven ECS). The total energy saving of $\mathrm{A} / \mathrm{C}$ is $52 \%$ over the entire test period.
\end{abstract} (C) 2010 Elsevier Ltd. All rights reserved.

\section{Introduction}

Ejector cooling system (ECS) using low boiling point refrigerant is suitable for solar cooling application due to its simple design and low cost [1-13]. If the ECS was driven by solar energy, it requires a back-up heater to make up the heat in order to keep a constant cooling capacity for space cooling during cloudy or rainy periods. Heat supplied by fossil fuel or electricity was generally adopted. This however causes a problem of additional investment of heaters and low efficiency in heat supply.

The New Energy Center at National Taiwan University has been devoted to the development of solar-assisted ejector cooling/ heating system $(\mathrm{SACH})$. The $\mathrm{SACH}$ consists of a conventional inverter-type air conditioner $(\mathrm{A} / \mathrm{C})$ made of variable-speed compressor connected in series or parallel with a solar ejector cooling system. SACH-1 is in series configuration and linked with a pump-less ejector cooling system with an inverter-type air conditioner to provide a stable space cooling [13]. SACH-2 is in parallel configuration as shown in Fig. 1. The ejector cooling system (ECS) driven by solar heat is connected in parallel with an invertertype air conditioner. The energy consumption of the air conditioner can be reduced by regulating the rotational speed of the

\footnotetext{
* Corresponding author. Tel.: +886 2 23634790; fax: +886 223640549 .

E-mail address: bjhuang@seed.net.tw (B.J. Huang).
}

compressor when the ECS is operating. During cloudy or rainy periods or at night, $\mathrm{SACH}-2$ will provide the entire cooling load from the inverter-type air conditioner (heat pump) as usual.

In the ECS, the condenser temperature must be lower than the critical condensing temperature (critical point) such that the ejector can operate at double-choking condition to obtain a better performance [2]. Otherwise, the cooling capacity will drop dramatically and the ECS may even loss the cooling performance completely and induce a reverse operation (heating). For a fixed geometry ejector which is designed for a particular double-choking critical condition (design point), the ECS will operate at off-design condition if the generator, evaporator, and condenser temperatures are not at the design point due to the environmental variations. For an ejector with fixed geometry, the critical condensing temperature depends on the generator temperature [2] which will vary with solar radiation intensity in solar cooling application. Therefore, the cooling performance of ECS may cease and a heating performance may be induced during the periods of lower solar radiation. The $\mathrm{SACH}$ will have a serious problem under variable weather condition, if this is not solved.

To solve this problem, the expansion valve installed in the suction line of the ejector (at the evaporator inlet) can be replaced by an electronic expansion valve to regulate the opening to control the suction flowrate to the ejector. The valve is completely closed when a reverse flow will occur. The preliminary field test result 


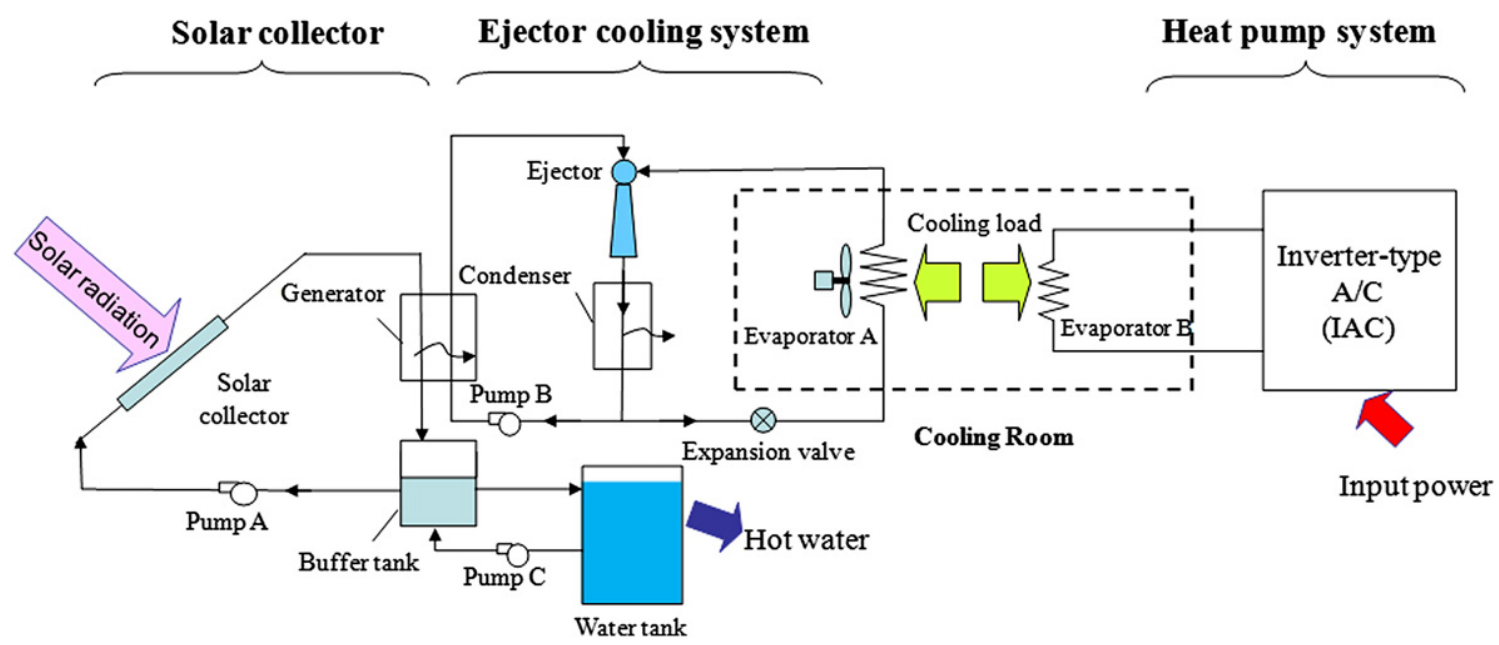

Fig. 1. Solar-assisted cooling/heating system in parallel configuration (SACH-2).

using a simple on/off control of the valve has shown that the performance of SACH-2 was improved [14]. However, it still needs a good feedback control system to control the valve opening according to the variations of environment.

In the present study, an optimal control technology is further developed to cope with this field operation problem of SACH-2. The opening of the electronic expansion is regulated automatically to control the evaporator temperature according to the variation of solar radiation intensity. This will make the $\mathrm{SACH}-2$ always produce cooling effect even at lower solar radiation periods while the ejector performs at off-design conditions.

\section{Experimental setup}

\subsection{System design of $\mathrm{SACH}-2$}

SACH-2 consists of 3 subsystems: an ejector cooling system, a solar collector system, and an inverter-type air conditioner with variable-speed compressor. Fig. 2 is the schematic diagram of a practical SACH-2. The SACH-2 uses an inverter-type air conditioner with rated cooling capacity $3.6 \mathrm{~kW}$ (1RT). The cooling capacity of the ECS is designed at $1.8 \mathrm{~kW}$ rated at critical condenser temperature $38{ }^{\circ} \mathrm{C}$, generator temperature $100^{\circ} \mathrm{C}$, and evaporator

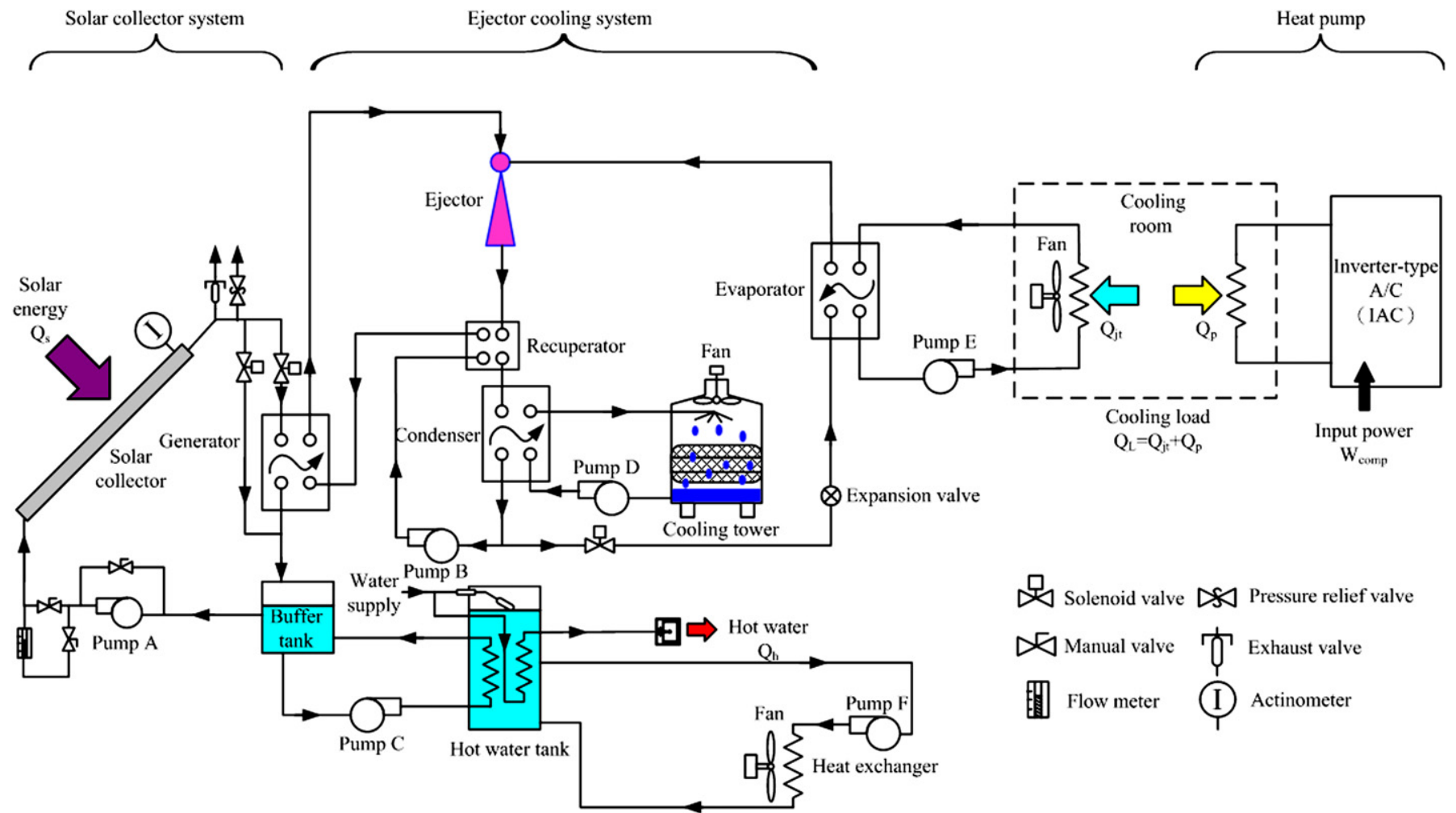

Fig. 2. Schematic diagram of a practical SACH-2. 
Table 1

Overall system design specification of SACH-2.

\begin{tabular}{ll}
\hline 1. Inverter-type air-conditioner & Hitachi RAS-32JQ \\
Refrigerant & $\mathrm{R} 410 \mathrm{a}$ \\
Input voltage, $\mathrm{V}$ & $\mathrm{AC} 220$ \\
Compressor frequency, $\mathrm{Hz}$ & $20-80$ \\
Compressor input power, $\mathrm{kW}$ & $0.26-1.09$ \\
Cooling capacity at $54.4^{\circ} \mathrm{C}$ condenser $/ 7^{\circ} \mathrm{C}$ evaporator, $\mathrm{kW}$ & $1.0-4.2$ \\
Rated COP & 3.85 \\
2. Ejector cooling system & \\
Refrigerant & $\mathrm{R} 365 \mathrm{mfc}$ \\
Generator temperature, ${ }^{\circ} \mathrm{C}$ & 100 \\
Generator heat input, $\mathrm{kW}$ & 11 \\
Condenser capacity, $\mathrm{kW}$ & 12.8 \\
Condensing temperature, ${ }^{\circ} \mathrm{C}$ & 38 \\
Evaporator temperature, ${ }^{\circ} \mathrm{C}$ & 8 \\
Evaporator cooling capacity, $\mathrm{kW}$ & 1.8 \\
COP & 0.16 \\
\hline
\end{tabular}

Table 2

Specification of the vacuum-tube solar collector.

\begin{tabular}{ll}
\hline Total absorber area & $1.08 \mathrm{~m}^{2}$ \\
No. of vacuum tubes & 6 \\
Collector tube dimensions & $\$ 100 \times 2000 \mathrm{~mm}$ \\
Collection efficiency & $0.615 @ 120^{\circ} \mathrm{C}$ \\
\hline
\end{tabular}

temperature $8^{\circ} \mathrm{C}$. The overall system design specification is shown in Table 1. The ECS refrigerant is R365 mfc and the nozzle design is listed in Table 2 with $5.3 \mathrm{~mm}$ in the nozzle throat diameter, $10 \mathrm{~mm}$ in the nozzle exit diameter, $15.5 \mathrm{~mm}$ in constant-area chamber diameter, and $65^{\circ}$ in inlet converging angle. The ejector area ratio of constant-area section to nozzle throat is 8.55 which is designed for the operating condition of critical condenser temperature $38^{\circ} \mathrm{C}$, generator temperature $100^{\circ} \mathrm{C}$, and evaporator temperature $8^{\circ} \mathrm{C}$. The evaporator cooling capacity of the ECS is designed at $1.8 \mathrm{~kW}$ which will reduce the power consumption of inverter-type air conditioner by $50-70 \%$ at clear weather.

The ejector cooling system and the inverter-type air conditioner operate independently. There is a microprocessor-based central control system to effectively regulate the two systems according to the solar irradiation and solar collector system performance to reduce the input power of the inverter-type air conditioner. The condenser of the ejector cooling system is cooled by a conventional water cooling tower. An electronic expansion valve was installed in the suction line of the ejector (at the evaporator inlet) to regulate the opening to control the flowrate through the evaporator according to the variation of solar radiation intensity.

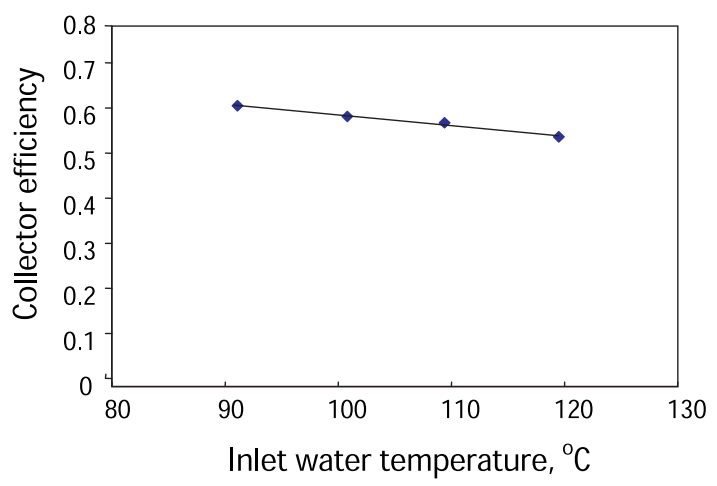

Fig. 3. Measured instantaneous solar collector efficiency of a single collector.

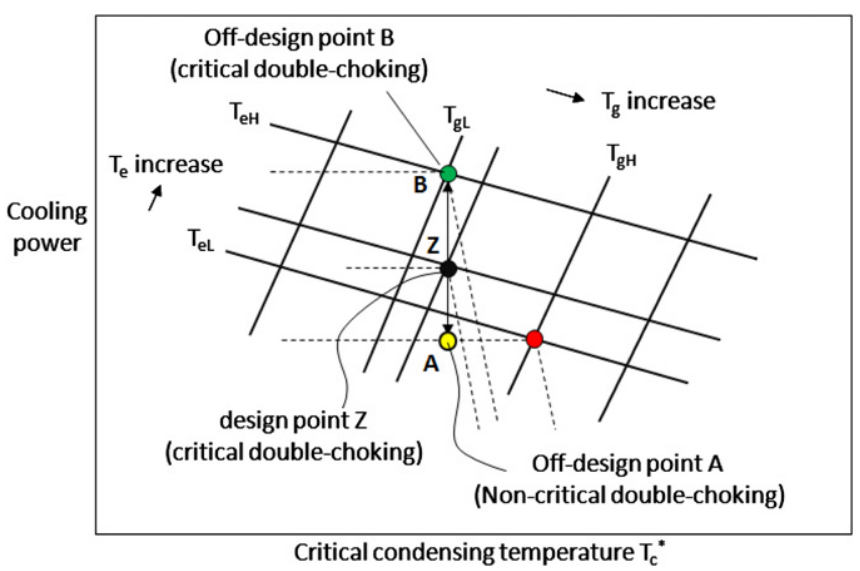

Fig. 4. Performance map of a fixed-geometry ejector.

\subsection{Solar heating system}

The solar heating system consists of 48 sets vacuum-tube solar collectors with $51.8 \mathrm{~m}^{2}$ total collector area (Table 2), a circulation pump, and a buffer tank used to stabilize the temperature to heat the generator of the ejector cooling system. The instantaneous thermal efficiency of the solar collector is 0.615 at water inlet temperature $120^{\circ} \mathrm{C}$. The measured solar energy collection efficiency is shown in Fig. 3. The test result shows that the solar energy collection efficiency is around 0.6 when the buffer tank temperature reaches $100^{\circ} \mathrm{C}$.

A PC-based control system was designed in the present study to control the ON/OFF of the circulation pump according to solar radiation variation. Temperature-difference controller based on the temperature difference between the collector outlet and the buffer tank was employed.

\subsection{ECS control system design}

In the ECS, the condensing temperature must be lower than the critical condensing temperature (critical point) such that the ejector can operate at double-choking condition. For an ejector with fixed geometry, the critical condensing temperature depends on the evaporator temperature and the generator temperature [2] which varies with solar radiation intensity. The ejector of the ECS will probably operate at off-design conditions due to the variation of solar radiation intensity.

The performance of an ECS operating at off-design condition can be analyzed using the performance map of the ejector [15], as shown in Fig. 4. At a fixed condensing temperature which is lower

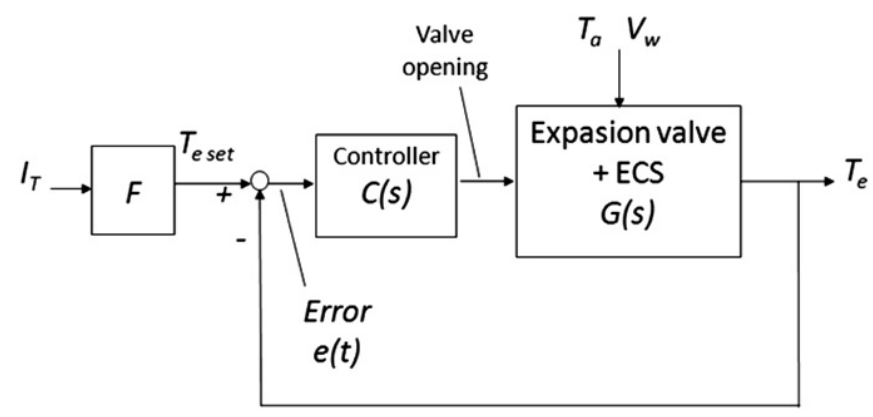

Fig. 5. Feedback control structure for ECS. 


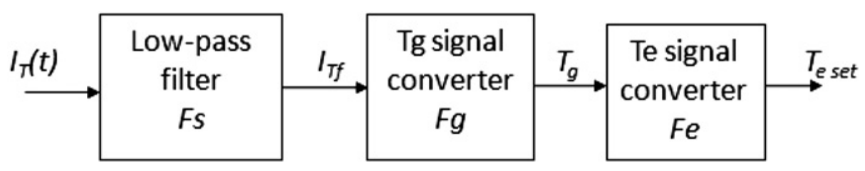

Fig. 6. Decomposition of filter $F$ in the feedback tracking control system.

than the critical condensing temperature (i.e., non-critical doublechoking condition), the evaporator temperature and cooling capacity will decrease to $T_{\mathrm{eL}}$ if the generator temperature increases to $T_{\mathrm{gH}}$. This follows the operating line $\mathrm{Z}-\mathrm{A}$ in Fig. 4. Furthermore, if the generator temperature decreases to $T_{\mathrm{gL}}$ and the ejector wants to operate at a critical double-choking condition, the evaporator temperature needs to be increased to $T_{\mathrm{eH}}$ in order to keep the ejector working at double-choking condition. This follows the operating line $\mathrm{Z}-\mathrm{B}$ in Fig. 4. The operating condition of constant condensing temperature happens very often since the water temperature of the condenser cooling tower of the ECS varies very little if the ambient temperature varies slowly.

In order to make the ejector operate at critical or non-critical double-choking condition to obtain a better performance, an electronic expansion valve was installed in the suction line of the ejector (at the evaporator inlet) to regulate the opening of the expansion valve to control the evaporator temperature. A feedback tracking control system was then designed according to the structure shown in Fig. 5. The tracking control is for adjusting the evaporator temperature $T_{\mathrm{e}}(t)$ which may vary with instantaneous solar radiation intensity $I_{\mathrm{T}}(t)$. Hence, a filter $F$ is needed to convert the signal $I_{\mathrm{T}}(t)$ into the setting value of evaporator temperature $T_{\mathrm{e}}$, set $(t)$ for tracking control as shown in Fig. 6.

Since the setting of evaporator temperature $T_{\mathrm{e}, \text { set }}$ will directly depend on the generator temperature $T_{\mathrm{g}}$. A converter $\left(T_{\mathrm{e}}\right.$ signal converter) can be defined as a functional relation of generator temperature, $F_{\mathrm{e}}$. The generator temperature will further depend on the solar radiation intensity. Another converter $\left(T_{\mathrm{g}}\right.$ signal converter) can be defined as a functional relation of solar radiation intensity incident upon solar collector $I_{\mathrm{Tf}}, F_{g}$. The two signal converters $F_{\mathrm{e}}$ and $F_{\mathrm{g}}$ can be determined from the field test of the $\mathrm{SACH}-2$.

To determine the two signal converters $F_{\mathrm{e}}$ and $F_{\mathrm{g}}$, the SACH-2 was run continuously and the electronic expansion valve was adjusted manually to regulate the evaporator temperature according to the generator temperature such that the ECS still produce cooling effect at off-design condition. Table 3 are the measured $T_{\mathrm{e}}$ with respect to $T_{\mathrm{g}}$ at different ambient temperature. Each data points are taken from steady-state performance at about 20-30 min time interval. Fig. 7 shows that $T_{\mathrm{e}}$ decreases linearly with increasing $T_{\mathrm{g}}$. A linear relation can be derived for the $T_{\mathrm{e}}$-signal converter $F_{\mathrm{e}}$ as

$T_{\mathrm{e}}=-0.7446 T_{\mathrm{g}}+86.1$,

Table 3

Experimental results of $T_{\mathrm{e}}$ regulation.

\begin{tabular}{llr}
\hline$T_{\mathrm{a}}\left({ }^{\circ} \mathrm{C}\right)$ & 35.5 & 32.7 \\
\hline$T_{\mathrm{g}}\left({ }^{\circ} \mathrm{C}\right)$ & $T_{\mathrm{e}}\left({ }^{\circ} \mathrm{C}\right)$ & \\
85 & 24.8 & 20.7 \\
90 & 21.0 & 17.2 \\
95 & 17.1 & 13.6 \\
100 & 13.2 & 10.0 \\
105 & 9.4 & 6.4 \\
110 & 5.5 & 2.8 \\
\hline
\end{tabular}

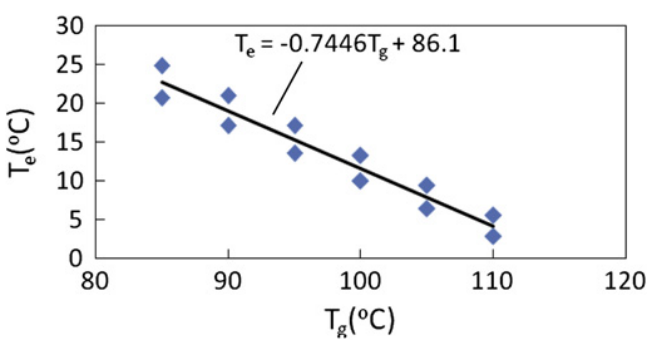

Fig. 7. Experimental results of $T_{\mathrm{e}}$ regulation.

Table 4

Experimental results of $T_{g}$ variation with solar radiation intensity.

\begin{tabular}{lcccc}
\hline Date & $2009 / 10 / 2$ & $2009 / 10 / 14$ & $2009 / 10 / 26$ & $2009 / 11 / 24$ \\
\hline$T_{\mathrm{a}}\left({ }^{\circ} \mathrm{C}\right)$ & 35.5 & 32.7 & 30.7 & 27.8 \\
$I_{\mathrm{Tf}}\left(\mathrm{W} / \mathrm{m}^{2}\right)$ & $T_{\mathrm{g}}\left({ }^{\circ} \mathrm{C}\right)$ & & & \\
500 & 98.8 & 96.1 & 95 & 94.5 \\
600 & 100.2 & 98.4 & 97.7 & 97.9 \\
700 & 101.6 & 100.8 & 100.4 & 101.2 \\
800 & 103 & 103.2 & 103.1 & \\
\hline
\end{tabular}

From the energy balance of the solar heating system and the generator, the generator temperature will depend on the solar radiation intensity and the cooling load. Table 4 shows the variation of $T_{\mathrm{g}}$ with solar radiation intensity $I_{\mathrm{Tf}}$ and ambient temperature $T_{\mathrm{a}}$. Each data points are taken from steady-state performance at about 20-30 min time interval. Fig. 8 shows that $T_{\mathrm{g}}$ increases linearly with $I_{\mathrm{Tf}}$ at ambient temperature in the range $27.8-35.5^{\circ} \mathrm{C}$. A linear relation can be derived for the $T_{\mathrm{g}}$-signal converter $F_{\mathrm{g}}$ as

$T_{\mathrm{g}}=0.0216 I_{\mathrm{Tf}}+85.84$,

The low-pass filter $F_{\mathrm{S}}$ in Fig. 6 is used to filter the fast variation of solar radiation signal, i.e. low pass, since only low-frequency content of the solar radiation variation will affect the response of the generator temperature. Hence, the filter $F_{\mathrm{s}}$ is designed as a lowpass filter using moving average, i.e. MA filter, with fixed time interval $8 \mathrm{~min}$.

The controller $C(s)$ of the tracking feedback control system uses the proportional control algorithm with proportional gain 0.33 . A PC-based control system was developed to control the solar heating system, the ECS and the whole SACH-2 operation. The monitoring system collects the data every $10 \mathrm{~s}$. Fig. 9 shows the outlook of the whole SACH-2.

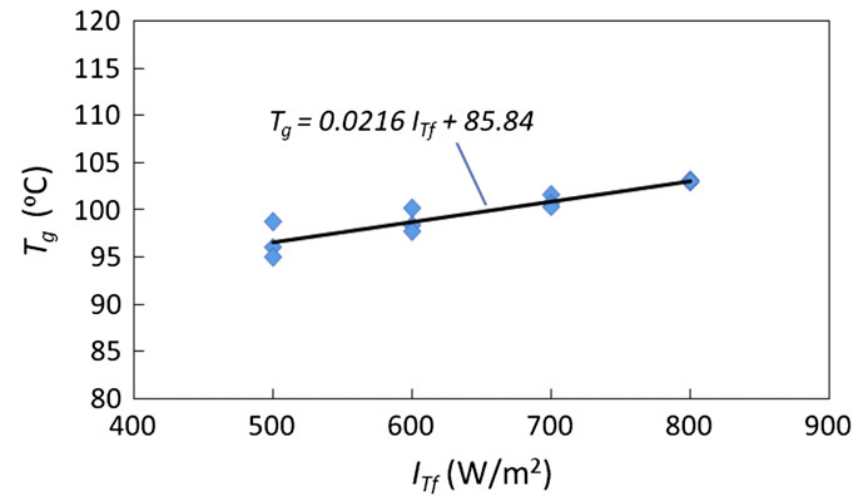

Fig. 8. Experimental results of $T_{g}$ variation with solar radiation intensity. 


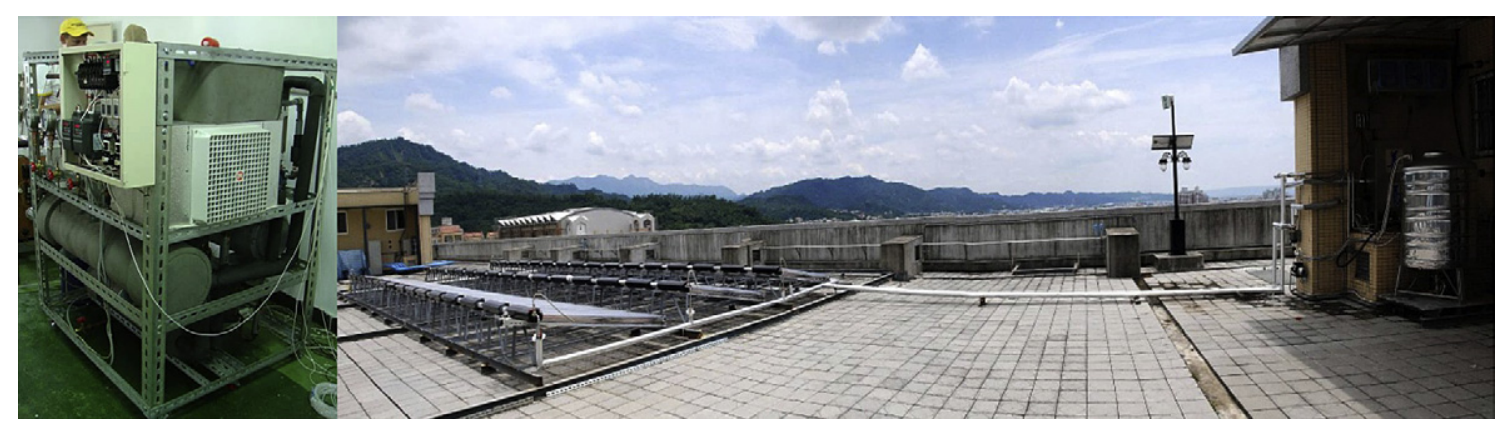

Fig. 9. Outlook of SACH-2 (left: ECS, right: solar heating system).

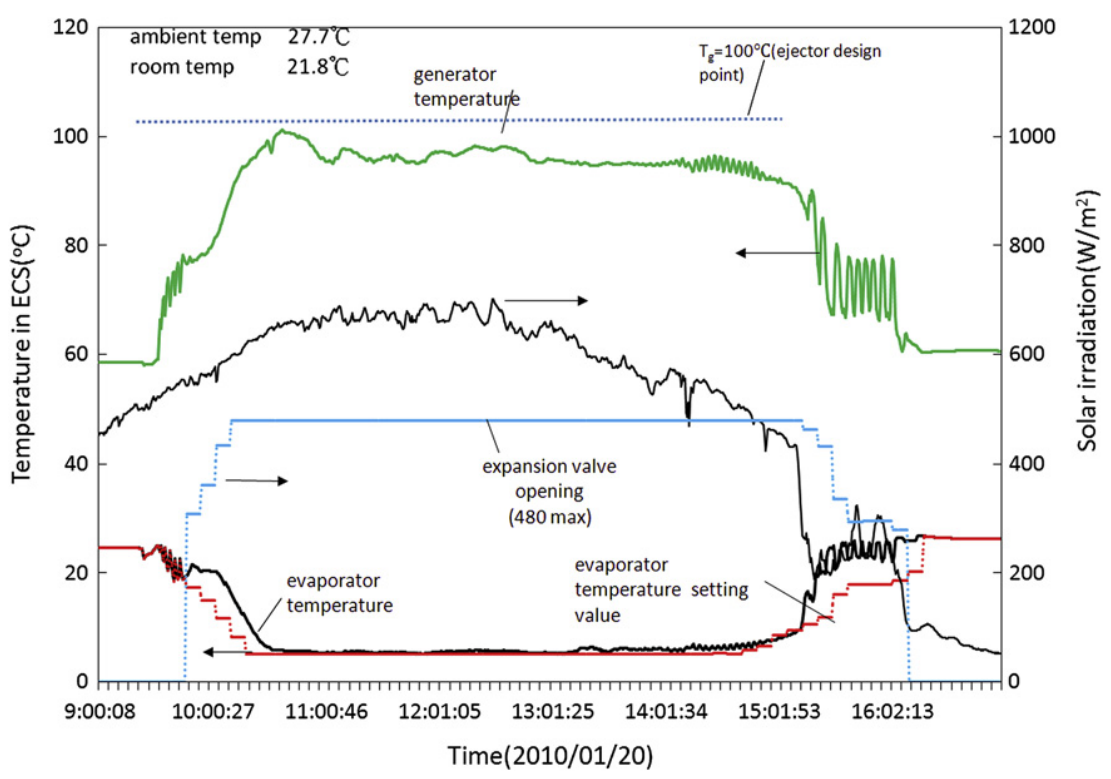

Fig. 10. Performance of SACH-2 (2010/1/20) - fair sunny day.

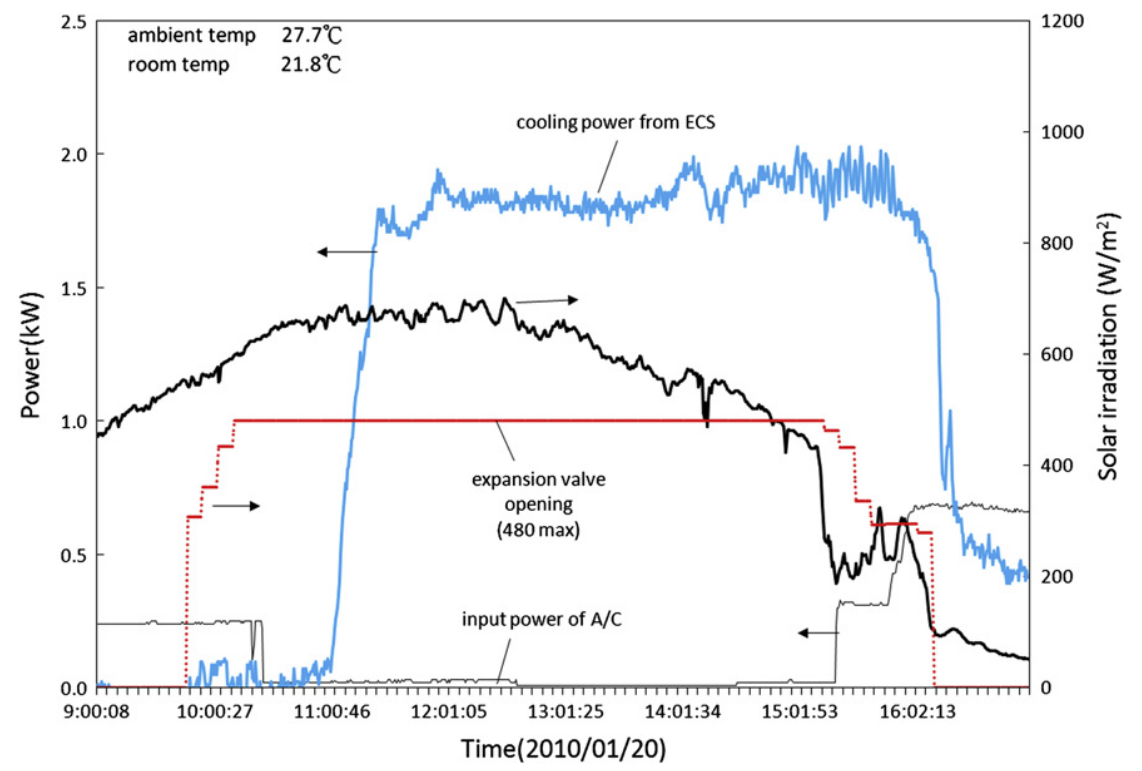

Fig. 11. Performance of SACH-2 (2010/1/20) - fair sunny day. 


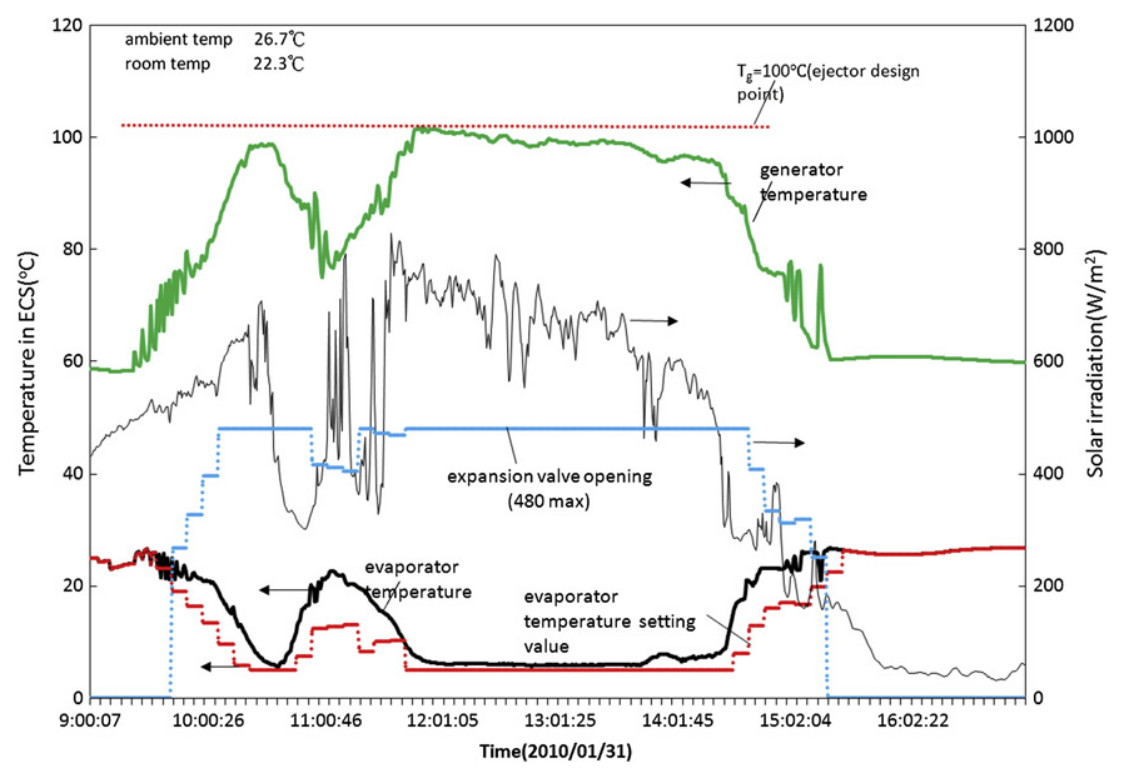

Fig. 12. Performance of SACH-2 (2010/1/31) - partly cloudy day.

\section{Field test of SACH-2}

The field test of SACH-2 was run continuously to monitor the system performance, including the regulation of evaporator temperature and the performance of ECS, the power input to the air conditioner $(\mathrm{A} / \mathrm{C})$, and the power input reduction (energy saving) of the $A / C$ at various weather conditions.

\subsection{Performance of SACH at various weather}

Fig. 10 shows the test results on a fair sunny day without cloud but having weaker solar radiation. The tested indoor-outdoor temperature difference is $5.9^{\circ} \mathrm{C}$ which corresponds to a medium cooling load. It is seen that the evaporator temperature setting value varies with the generator temperature. The control system tends to track the evaporator temperature setting values. The maximum tracking error is about $5^{\circ} \mathrm{C}$ which happens during low solar radiation periods around 15:30PM. During 10:40-15:00, the generator temperature is mostly higher than $95^{\circ} \mathrm{C}$ near the design point $\left(100^{\circ} \mathrm{C}\right.$ ) and the evaporator temperature around $6{ }^{\circ} \mathrm{C}$ (near the design point $8^{\circ} \mathrm{C}$ ). The expansion valve is fully opened.

It is seen from Fig. 11 that the ECS still works at off-design point of ejector with double-choking and provides cooling power after 15:30PM when solar radiation intensity drops while the generator temperature is only around $70^{\circ} \mathrm{C}$. The evaporator temperature is changed to about $20^{\circ} \mathrm{C}$. After 16:00PM, the ECS ceases to work and the power input of the $A / C$ is $0.68 \mathrm{~kW}$ which represents the power input to the cooling load of the room without the ECS. During $15: 30 \mathrm{PM}$ to $16: 00 \mathrm{PM}$, the input power to $\mathrm{A} / \mathrm{C}$ is around $0.31 \mathrm{~kW}$ while the ECS is working. This means that a reduction of input power of $\mathrm{A} / \mathrm{C}$ is around 54\% due to the cooling performance of ECS driven by solar heat.

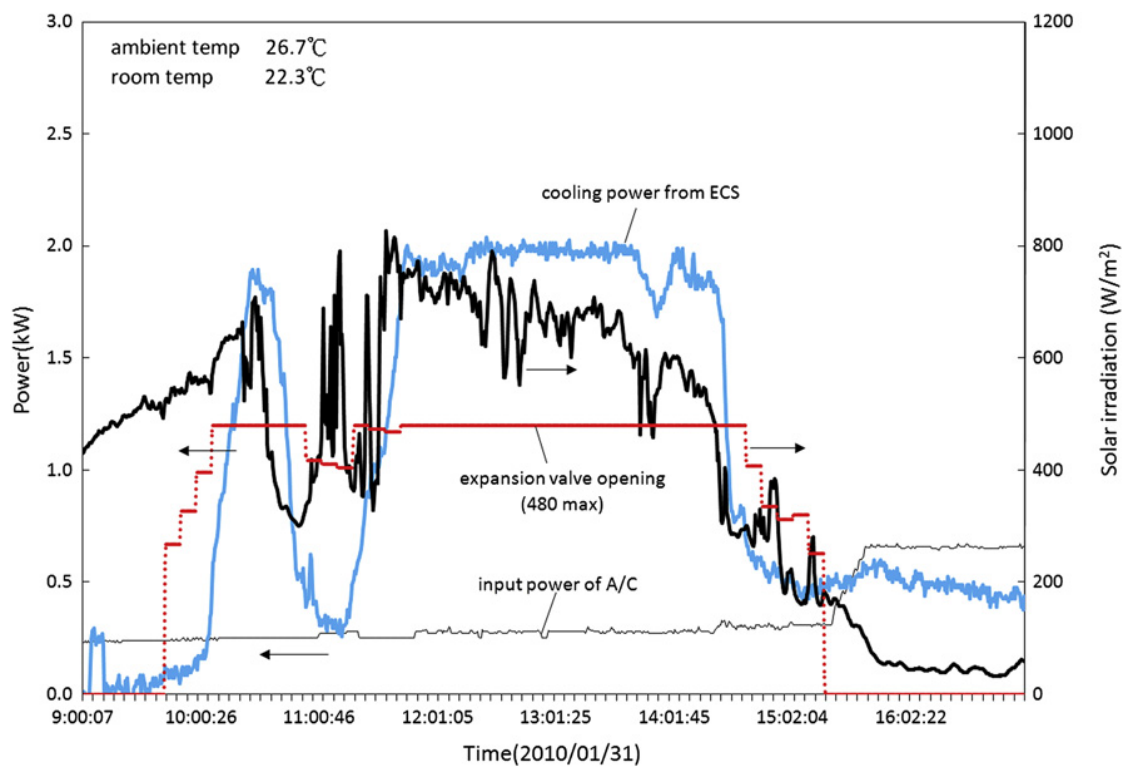

Fig. 13. Performance of SACH-2 (2010/1/31) - partly cloudy day. 


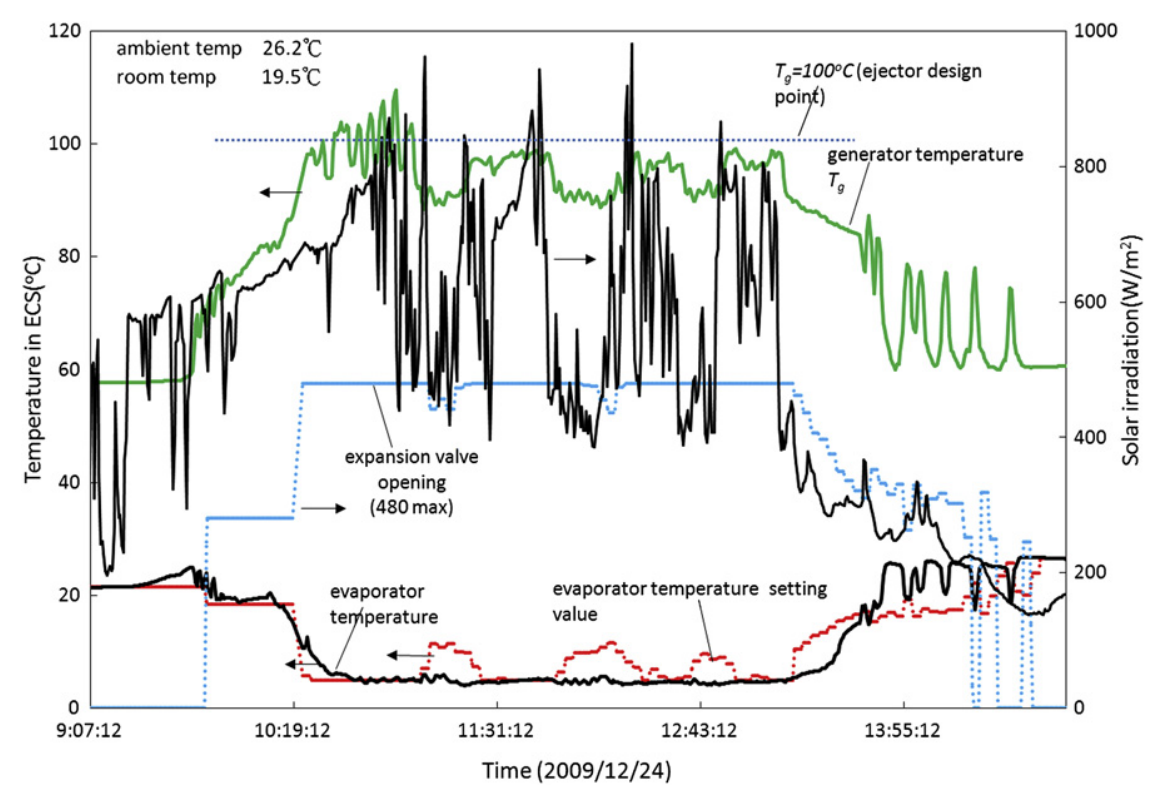

Fig. 14. Performance of SACH-2 (2009/12/24) - cloudy day.

There is time lag around 10:00AM due to thermal response of the generator temperature. During the period 11:00AM to 15:00PM, the ECS performs very well at high solar radiation intensity. The generator temperature is mostly higher than $95^{\circ} \mathrm{C}$ near the design point $\left(100^{\circ} \mathrm{C}\right)$ and the evaporator temperature around $7{ }^{\circ} \mathrm{C}$ (near the design point $8{ }^{\circ} \mathrm{C}$ ). The input power of the $\mathrm{A} / \mathrm{C}$ is almost zero, i.e. $100 \%$ energy saving, since the ECS supplies almost all the cooling load. The test results have shown that the tracking control system works and the ECS can produce cooling effect at offdesign conditions at low solar radiation periods around 15:30PM.

Fig. 12 shows the test results on a partly cloudy day with indoor-outdoor temperature difference $4.4{ }^{\circ} \mathrm{C}$ (low cooling load). It is seen that the evaporator temperature setting value varies with the generator temperature. And the tracking control system tends to track the evaporator temperature setting values. The maximum tracking error is about $8{ }^{\circ} \mathrm{C}$ which happens during a sudden drop and rise of solar radiation and generator temperature around 11AM. During 12:00-14:30, the generator temperature is mostly higher than $95{ }^{\circ} \mathrm{C}$ near the design point $\left(100^{\circ} \mathrm{C}\right)$ and the evaporator temperature around $6{ }^{\circ} \mathrm{C}$ (near the design point $8^{\circ} \mathrm{C}$ ).

Fig. 13 shows that the cooling power from ECS varies with the solar radiation intensity. The input power of $\mathrm{A} / \mathrm{C}$ is around $0.66 \mathrm{~kW}$ at 16PM when the ECS ceases to work. During the period 14:30PM to $15: 30 \mathrm{PM}$ at very low solar radiation intensity, the ECS still works at off-design conditions and provide some cooling power. The input power of $A / C$ is around $0.31 \mathrm{~kW}$. This means that the reduction of input power of $\mathrm{A} / \mathrm{C}$ is around $53 \%$ due to the performance of $\mathrm{ECS}$.

Fig. 14 shows the test results on a cloudy day with indoor-outdoor temperature difference $6.7^{\circ} \mathrm{C}$ (medium cooling load). It is seen that the evaporator temperature setting value varies with the generator temperature. Before 9:40AM, the solar radiation is low and varies. The SACH-2 is at start-up period and the

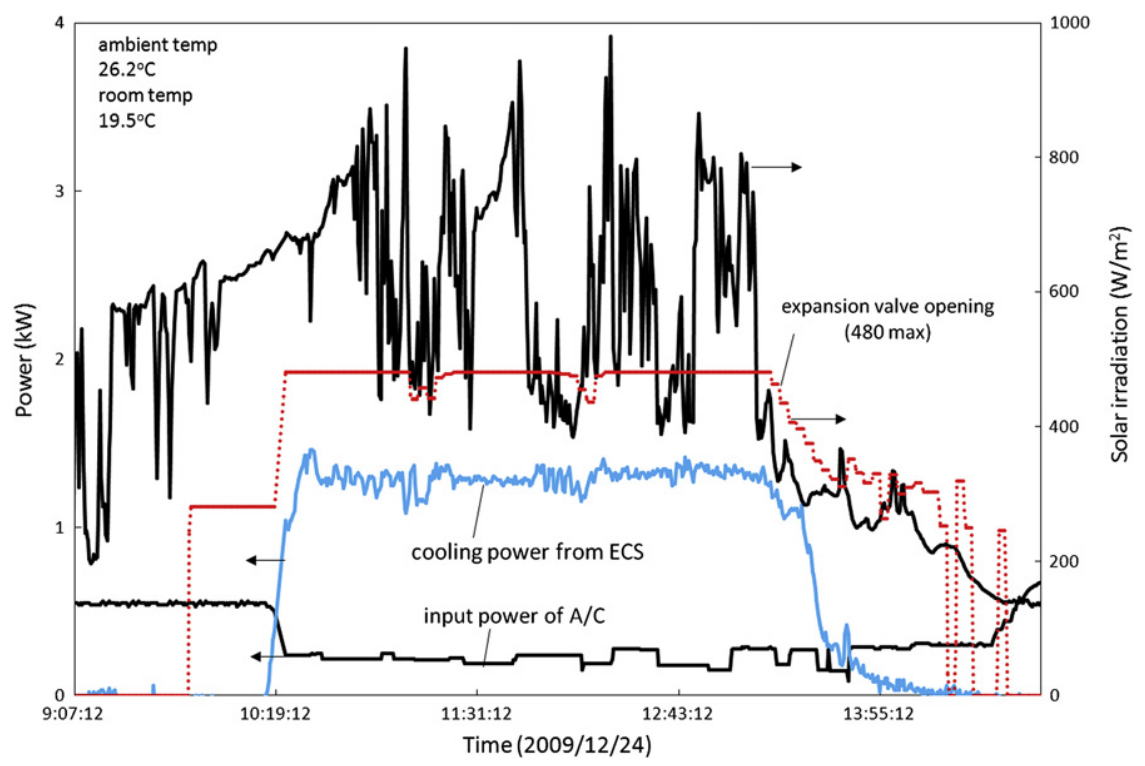

Fig. 15. Performance of SACH-2 (2009/12/24) - cloudy day. 


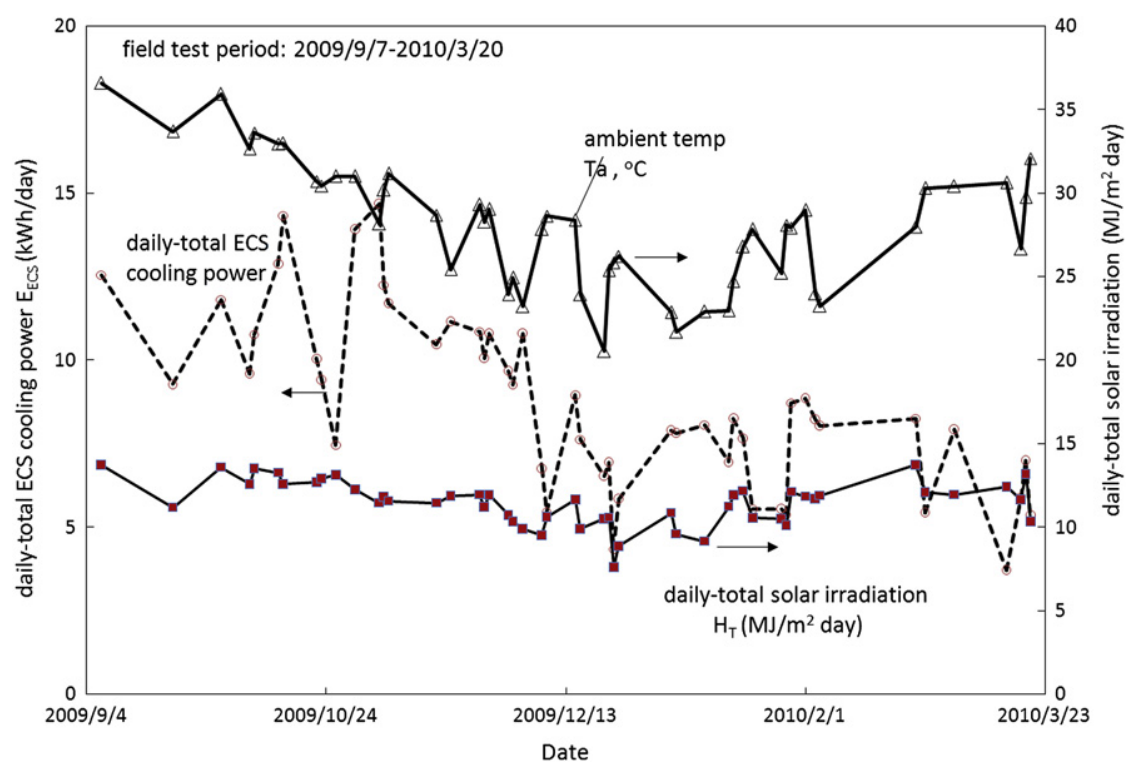

Fig. 16. Long-term performance test results of SACH-2.

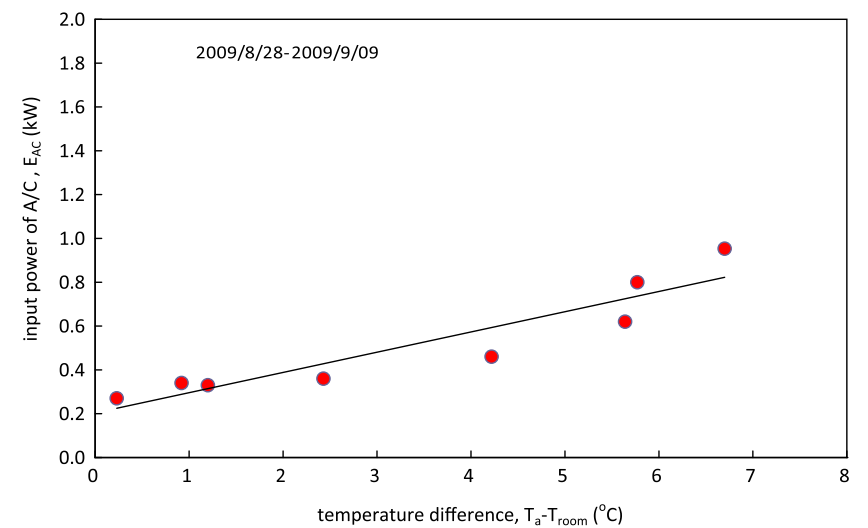

Fig. 17. Input power of $\mathrm{A} / \mathrm{C}$ alone (without $\mathrm{ECS}$ ). expansion valve is closed. The tracking control is not activated. After that, the tracking control system starts to track the evaporator temperature setting values. The maximum tracking error is about $5{ }^{\circ} \mathrm{C}$ which happens when there is a sudden drop of solar radiation and generator temperature around 10:50AM, 12:10PM, 12:43PM and after 13:50PM. After 13:00PM, the solar radiation intensity drops quickly and the generator temperature decreases to below $80^{\circ} \mathrm{C}$. After $14: 00 \mathrm{PM}$ at low solar radiation $\left(<300 \mathrm{~W} / \mathrm{m}^{2}\right)$, the generator temperature fluctuates between $60^{\circ} \mathrm{C}$ and $80^{\circ} \mathrm{C}$.

Fig. 15 shows that the cooling power from ECS varies with the solar radiation intensity. The input power of $\mathrm{A} / \mathrm{C}$ is around $0.55 \mathrm{~kW}$ before 9:40AM when the ECS has not started to work yet. During the period 10:00AM to 13:30PM at moderate solar radiation intensity, the ECS works and provide some cooling power. The input power of $\mathrm{A} / \mathrm{C}$ is around $0.2 \mathrm{~kW}$. This means that the reduction of input power of $\mathrm{A} / \mathrm{C}$ is around $63 \%$ due to the cooling performance of ECS. After

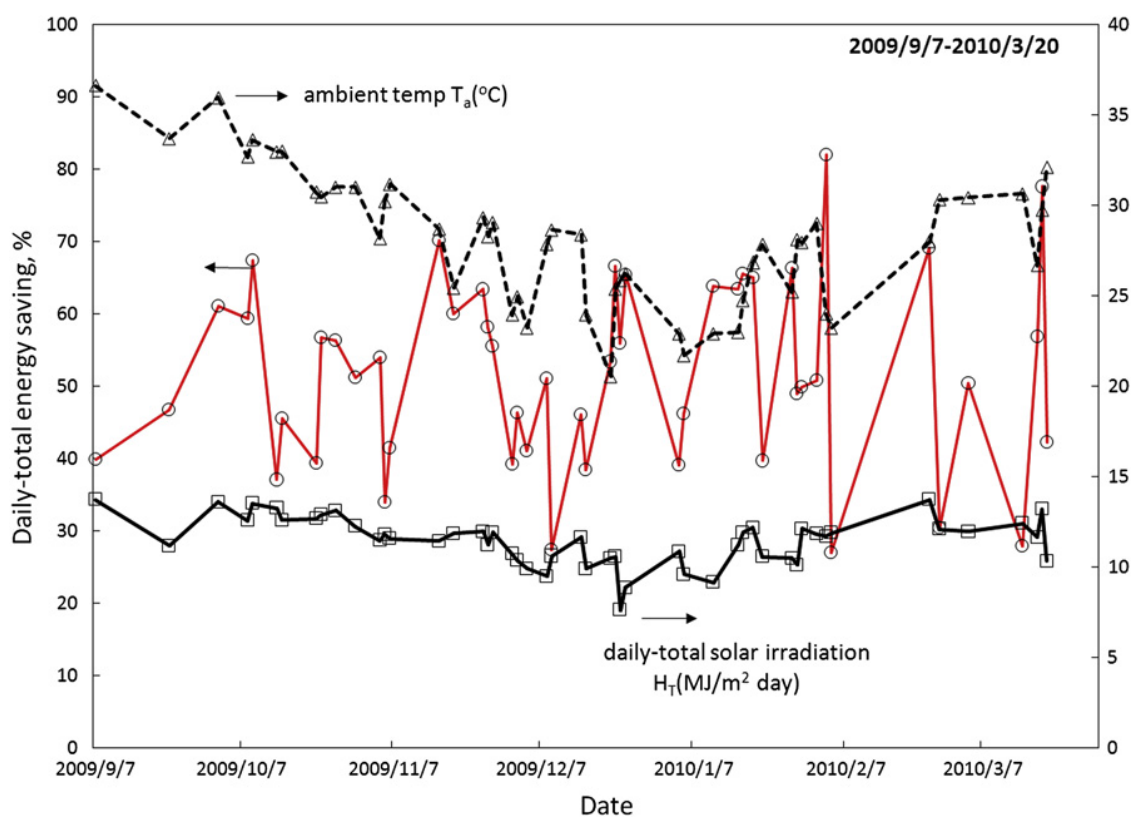

Fig. 18. Long-term performance test results of SACH-2. 
Table 5

Long-term performance test results of SACH-2 (2009/09/07-2010/03/20).

\begin{tabular}{|c|c|c|c|c|c|c|c|c|c|}
\hline Data & $\begin{array}{l}\text { Solar irradiation, } \\
H_{\mathrm{T}} \mathrm{MJ} / \mathrm{m}^{2} \text { day }\end{array}$ & $\begin{array}{l}T_{\mathrm{a}} \\
\left({ }^{\circ} \mathrm{C}\right)\end{array}$ & $\begin{array}{l}T_{\text {room }} \\
\left({ }^{\circ} \mathrm{C}\right)\end{array}$ & $\begin{array}{l}\text { Room temp } \\
\text { difference } \\
T_{\mathrm{a}}-T_{\text {room }}\left({ }^{\circ} \mathrm{C}\right)\end{array}$ & $\begin{array}{l}\text { Power consumption } \\
\text { of } \mathrm{A} / \mathrm{C}, E_{\mathrm{AC}}(\mathrm{kWh})\end{array}$ & $\begin{array}{l}\text { Cooling power } \\
\text { from ECS, } \\
L_{\mathrm{ECS}}(\mathrm{kWh})\end{array}$ & $\begin{array}{l}\text { Power consumption } \\
\text { of } \mathrm{A} / \mathrm{C} \text { alone, } \\
E_{\mathrm{AC}} 0(\mathrm{kWh})\end{array}$ & $\begin{array}{l}E_{\text {SAVING }} \\
(\mathrm{kWh})\end{array}$ & $\begin{array}{l}\text { Daily-total } \\
\text { energy saving } \\
(\%)\end{array}$ \\
\hline $2009 / 9 / 7$ & 13.7 & 36.6 & 27.6 & 9.1 & 3.12 & 12.55 & 5.20 & 2.07 & 39.9 \\
\hline $2009 / 9 / 22$ & 11.2 & 33.7 & 26.8 & 6.9 & 2.23 & 9.29 & 4.20 & 1.96 & 46.8 \\
\hline $2009 / 10 / 2$ & 13.6 & 36.0 & 27.0 & 9.0 & 1.99 & 11.81 & 5.12 & 3.13 & 61.1 \\
\hline $2009 / 10 / 8$ & 12.6 & 32.7 & 24.6 & 8.1 & 1.93 & 9.60 & 4.75 & 2.82 & 59.4 \\
\hline $2009 / 10 / 9$ & 13.5 & 33.6 & 25.2 & 8.5 & 1.61 & 10.77 & 4.92 & 3.32 & 67.4 \\
\hline $2009 / 10 / 14$ & 13.3 & 33.0 & 26.5 & 6.5 & 2.53 & 12.89 & 4.01 & 1.49 & 37.1 \\
\hline $2009 / 10 / 15$ & 12.6 & 33.0 & 27.0 & 6.0 & 2.07 & 14.32 & 3.80 & 1.73 & 45.5 \\
\hline $2009 / 10 / 22$ & 12.7 & 30.7 & 24.9 & 5.8 & 2.25 & 10.05 & 3.71 & 1.46 & 39.4 \\
\hline $2009 / 10 / 23$ & 12.9 & 30.5 & 24.8 & 5.6 & 1.56 & 9.41 & 3.61 & 2.05 & 56.7 \\
\hline $2009 / 10 / 26$ & 13.1 & 31.0 & 24.4 & 6.6 & 1.77 & 7.45 & 4.06 & 2.29 & 56.4 \\
\hline $2009 / 10 / 30$ & 12.3 & 31.0 & 25.1 & 6.0 & 1.84 & 13.92 & 3.77 & 1.93 & 51.2 \\
\hline $2009 / 11 / 4$ & 11.5 & 28.2 & 22.8 & 5.4 & 1.61 & 14.69 & 3.49 & 1.89 & 54.0 \\
\hline $2009 / 11 / 5$ & 11.8 & 30.2 & 24.5 & 5.7 & 2.45 & 12.25 & 3.64 & 1.24 & 34.0 \\
\hline $2009 / 11 / 6$ & 11.6 & 31.2 & 24.3 & 6.9 & 2.45 & 11.71 & 4.18 & 1.73 & 41.4 \\
\hline $2009 / 11 / 16$ & 11.5 & 28.7 & 21.9 & 6.8 & 1.24 & 10.48 & 4.17 & 2.93 & 70.2 \\
\hline $2009 / 11 / 19$ & 11.9 & 25.4 & 21.6 & 3.9 & 1.12 & 11.17 & 2.82 & 1.69 & 60.1 \\
\hline $2009 / 11 / 25$ & 12.0 & 29.3 & 22.6 & 6.8 & 1.52 & 10.85 & 4.14 & 2.63 & 63.4 \\
\hline $2009 / 11 / 26$ & 11.2 & 28.3 & 22.3 & 6.0 & 1.59 & 10.07 & 3.80 & 2.21 & 58.2 \\
\hline $2009 / 11 / 27$ & 11.9 & 29.0 & 24.1 & 4.9 & 1.47 & 10.81 & 3.29 & 1.83 & 55.5 \\
\hline $2009 / 12 / 1$ & 10.7 & 24.0 & 21.9 & 2.1 & 1.20 & 9.69 & 1.98 & 0.77 & 39.2 \\
\hline $2009 / 12 / 2$ & 10.4 & 25.0 & 20.4 & 4.5 & 1.89 & 9.26 & 3.12 & 1.45 & 46.4 \\
\hline $2009 / 12 / 4$ & 9.9 & 23.2 & 20.2 & 3.0 & 1.64 & 10.80 & 2.40 & 0.99 & 41.1 \\
\hline $2009 / 12 / 8$ & 9.5 & 27.9 & 21.0 & 6.9 & 2.05 & 6.75 & 4.20 & 2.14 & 51.1 \\
\hline $2009 / 12 / 9$ & 10.6 & 28.7 & 22.6 & 6.1 & 3.02 & 5.46 & 3.82 & 1.05 & 27.4 \\
\hline $2009 / 12 / 15$ & 11.7 & 28.4 & 22.4 & 6.0 & 2.08 & 8.96 & 3.81 & 1.75 & 46.0 \\
\hline $2009 / 12 / 16$ & 9.9 & 23.9 & 21.7 & 2.2 & 1.80 & 7.62 & 2.03 & 0.23 & 38.4 \\
\hline $2009 / 12 / 21$ & 10.5 & 20.5 & 17.6 & 2.9 & 1.36 & 6.54 & 2.38 & 1.27 & 53.4 \\
\hline $2009 / 12 / 22$ & 10.6 & 25.4 & 18.3 & 7.0 & 1.42 & 6.95 & 4.27 & 2.85 & 66.7 \\
\hline $2009 / 12 / 23$ & 7.6 & 25.9 & 19.5 & 6.4 & 2.12 & 4.33 & 3.96 & 2.21 & 56.0 \\
\hline $2009 / 12 / 24$ & 8.9 & 26.2 & 19.7 & 6.5 & 1.39 & 5.85 & 4.04 & 2.65 & 65.5 \\
\hline $2010 / 1 / 4$ & 10.9 & 22.9 & 18.8 & 4.08 & 1.77 & 7.90 & 2.90 & 1.14 & 39.2 \\
\hline $2010 / 1 / 5$ & 9.6 & 21.7 & 19.2 & 2.45 & 1.16 & 7.82 & 2.15 & 0.99 & 46.2 \\
\hline $2010 / 1 / 11$ & 9.2 & 22.9 & 20.5 & 2.45 & 0.78 & 8.06 & 2.15 & 1.37 & 63.8 \\
\hline $2010 / 1 / 16$ & 11.2 & 23.0 & 18.1 & 4.92 & 1.20 & 6.96 & 3.29 & 2.09 & 63.5 \\
\hline $2010 / 1 / 17$ & 11.9 & 24.7 & 18.9 & 5.81 & 1.27 & 8.27 & 3.70 & 2.43 & 65.6 \\
\hline $2010 / 1 / 19$ & 12.2 & 26.8 & 20.2 & 6.61 & 1.42 & 7.67 & 4.07 & 2.65 & 65.0 \\
\hline $2010 / 1 / 21$ & 10.6 & 27.8 & 22.7 & 5.10 & 2.03 & 5.54 & 3.37 & 1.34 & 39.7 \\
\hline $2010 / 1 / 27$ & 10.5 & 25.2 & 19.6 & 5.61 & 1.21 & 5.55 & 3.61 & 2.39 & 66.3 \\
\hline $2010 / 1 / 28$ & 10.1 & 28.1 & 21.1 & 7.03 & 2.17 & 5.38 & 4.26 & 2.09 & 49.0 \\
\hline $2010 / 1 / 29$ & 12.1 & 27.9 & 21.4 & 6.54 & 2.02 & 8.71 & 4.04 & 2.01 & 49.9 \\
\hline $2010 / 2 / 1$ & 11.9 & 29.0 & 22.6 & 6.44 & 1.96 & 8.87 & 3.99 & 2.03 & 50.9 \\
\hline $2010 / 2 / 3$ & 11.7 & 24.0 & 22.0 & 2.01 & 0.35 & 8.24 & 1.95 & 1.59 & 82.0 \\
\hline $2010 / 2 / 4$ & 11.9 & 23.2 & 21.9 & 1.38 & 1.21 & 8.04 & 1.66 & 0.45 & 27.0 \\
\hline $2010 / 2 / 24$ & 13.7 & 28.0 & 20.4 & 7.58 & 1.39 & 8.25 & 4.52 & 3.12 & 69.1 \\
\hline $2010 / 2 / 26$ & 12.1 & 30.3 & 23.1 & 7.22 & 3.03 & 5.44 & 4.35 & 1.32 & 30.4 \\
\hline $2010 / 3 / 4$ & 12.0 & 30.4 & 24.2 & 6.20 & 1.92 & 7.93 & 3.88 & 1.95 & 50.4 \\
\hline $2010 / 3 / 15$ & 12.4 & 30.6 & 24.3 & 6.31 & 2.84 & 3.71 & 3.93 & 1.10 & 27.9 \\
\hline $2010 / 3 / 18$ & 11.7 & 26.7 & 22.5 & 4.15 & 1.26 & 5.90 & 2.93 & 1.67 & 56.9 \\
\hline $2010 / 3 / 19$ & 13.2 & 29.8 & 22.8 & 6.95 & 0.95 & 7.01 & 4.22 & 3.28 & 77.6 \\
\hline $2010 / 3 / 20$ & 10.3 & 32.1 & 25.0 & 7.06 & 2.47 & 5.36 & 4.28 & 1.81 & 42.3 \\
\hline Total & & & & & 88.76 & 436.93 & 181.94 & 94.57 & $52.0 \%$ \\
\hline
\end{tabular}

14:00PM, the ECS ceases at low solar radiation $\left(<300 \mathrm{~W} / \mathrm{m}^{2}\right)$ and the space cooling was completely provided by $\mathrm{A} / \mathrm{C}$. The power input of $\mathrm{A} / \mathrm{C}$ increases to $0.55 \mathrm{~kW}$.

SACH-2 has been tested continuously for about 7 months since Sept 7, 2009. Fig. 16 shows the variation of daily-total cooling power of ECS and the solar irradiation. It is seen that the daily-total cooling power provided by the ECS is more related to the ambient temperature.

In order to determine the input power reduction of $\mathrm{A} / \mathrm{C}$ in $\mathrm{SACH}-$ 2 , the input power of $A / C$ with respect to the room temperature difference $T_{\mathrm{a}}-T_{\text {room }}$ has to be determined experimentally first as the baseline. The data taken from running the $\mathrm{A} / \mathrm{C}$ alone are used to determine the correlation. Fig. 17 is the correlation between the input power of $\mathrm{A} / \mathrm{C}$ alone and the room temperature difference $T_{\mathrm{a}}-T_{\text {room }}$. This result is used to calculate the reduction of $\mathrm{A} / \mathrm{C}$ input power in the long-term field test of SACH-2.
Fig. 18 shows that the daily energy saving of SACH-2 is around $30-80 \%$ as compared to the energy consumption of $\mathrm{A} / \mathrm{C}$ alone (without solar-driven ECS). Table 5 summarizes the long-term performance test results of SACH-2 from 2009/09/07 to 2010/03/20. It is seen that the total energy saving of $\mathrm{A} / \mathrm{C}$ due to the cooling performance of ECS is $52 \%$.

\section{Discussions and conclusion}

The solar-assisted cooling system (SACH-2) was developed in the present study. The solar ejector cooling system is connected in parallel with an inverter-type air conditioner. The cooling load is supplied by the ECS when solar energy is available and the input power of the inverter-type $A / C$ can be reduced by regulating the rotational speed of the compressor. During cloudy or rainy periods 
or at night, SACH-2 will provide the entire cooling load from the inverter-type air conditioner (heat pump) as usual.

In cloudy or variable weather, the performance of $\mathrm{SACH}-2$ is rather complicated since solar radiation varies fast and unpredictable. The performance of the ECS will be at off-design conditions and the cooling capability of the ECS can be lost completely in cloudy or variable weather. In order to make the ejector operate at critical or non-critical double-choking condition to obtain a better performance, an electronic expansion valve was installed in the suction line of the ejector to regulate the opening of the expansion valve to control the evaporator temperature. A feedback tracking control system was designed for adjusting and tracking the evaporator temperature which may vary with solar radiation intensity. This will make the SACH-2 always produce cooling effect even at lower solar radiation periods while the ejector performs at offdesign conditions.

Field test results show that the regulation of the expansion valve is satisfactory and the ECS works properly and supplies cooling load at variable weather. The $\mathrm{A} / \mathrm{C}$ input power reduction can be achieved at low solar radiation periods while the ejector is working at offdesign condition. The reduction of input power of $\mathrm{A} / \mathrm{C}$ is $50-70 \%$ due to the cooling performance of ECS. The long-term performance test results of SACH-2 from 2009/09/07 to 2010/03/20 show that the daily energy saving of SACH-2 is around $30-70 \%$ as compared to the energy consumption of $\mathrm{A} / \mathrm{C}$ alone (without solar-driven ECS). It is seen that the total energy saving of $\mathrm{A} / \mathrm{C}$ due to the cooling performance of ECS is $52 \%$ over the entire test period.

The field test of SACH-2 at different weathers in the present study has verified the feasibility of optimal performance control of SACH-2 which keeps the ECS working at off-design double-choking condition by regulating the evaporator temperature. The feedback tracking control system is satisfactory although some defects still exist. The tracking error needs to be improved. This can be done by modifying the filter correlation $F$.

The filter $F$ is used to convert the instantaneous solar radiation intensity $I_{\mathrm{T}}(t)$ into the setting value of evaporator temperature $T_{e}$, set $(t)$ for tracking control. The two signal converters $F_{\mathrm{e}}$ and $F_{\mathrm{g}}$ (Fig. 6 ) were determined experimentally from field test. The SACH-2 was run continuously and the electronic expansion valve was adjusted manually to regulate the evaporator temperature according to the generator temperature such that the ECS still produce cooling effect at off-design point of the ejector. The $T_{\mathrm{e}}$-signal converter $F_{\mathrm{e}}$ which converts $T_{\mathrm{g}}$ into $T_{\mathrm{e}}$ was derived (Fig. 7) from the test data collected at the near-steady periods, about $20-30 \mathrm{~min}$ time interval, with variable solar radiation intensity. The experiment was performed at 6 different generator temperatures over the range $85-110^{\circ} \mathrm{C}$. It takes two working days for this field experiment. It will take longer for larger temperature range. However, this seems not necessary.

The determination of $T_{\mathrm{g}}$-signal converter $F_{\mathrm{g}}$ is rather complicated since the generator temperature will depend on the solar radiation intensity and the space cooling load (related to ambient temperature). It takes four working days in this experiment. More studies are required to obtain a better converter. The field test results of SACH-2 presented previously show that the expansion valve operates at saturation state (full-open) very often, even at ejector off-design point $\left(100^{\circ} \mathrm{C}\right)$. The size of the chosen expansion valve may be too small and needs re-examined and replaced.

In the future work, improvement of the filter $F_{\mathrm{e}}$ can also be made using a precise ejector performance map if available. The feedback controller can also be modified using a better controller design to take into account the thermal system response.

\section{Acknowledgements}

This publication is based on the work supported by Award No. KUK-C1-014-12, made by King Abdullah University of Science and Technology (KAUST).

\section{Nomenclature}

$H_{\mathrm{T}} \quad$ daily-total solar radiation intensity incident upon the collector slope, $\mathrm{MJ} \mathrm{m}^{-2}$ day $^{-1}$

$I_{\mathrm{T}}$ solar radiation intensity incident upon the collector slope, $\mathrm{W} \mathrm{m}^{-2}$

$I_{\mathrm{Tf}} \quad$ low-passed filtered signal of $I_{\mathrm{T}}, \mathrm{W} \mathrm{m}^{-2}$

$T_{\mathrm{a}} \quad$ ambient temperature, ${ }^{\circ} \mathrm{C}$

$T_{\mathrm{g}} \quad$ generator temperature of ECS, ${ }^{\circ} \mathrm{C}$

$T_{\mathrm{e}} \quad$ evaporator temperature of ECS, ${ }^{\circ} \mathrm{C}$

$T_{\mathrm{e}, \mathrm{set}}$ evaporator temperature setting of ECS, ${ }^{\circ} \mathrm{C}$

$T_{\mathrm{i}} \quad$ collector inlet temperature, ${ }^{\circ} \mathrm{C}$

$T_{\text {room }}$ room temperature, ${ }^{\circ} \mathrm{C}$

$Q_{c} \quad$ condenser heat rejection rate in the heat-driven cooler, $\mathrm{W}$

$Q_{e} \quad$ evaporator heat transfer rate in split-type air conditioner, $\mathrm{W}$

$Q_{g} \quad$ generator heat transfer rate in ejector cooling system, W $\eta \quad$ solar collector efficiency

\section{References}

[1] B.J. Huang, J.M. Chang, Empirical correlation for ejector design, Int. J. Refrig eration 22 (1999) 379-388.

[2] B.J. Huang, J.M. Chang, C.P. Wang, V.A. Petrenko, A 1D analysis of ejector performance, Int. J. Refrigeration 22 (1999) 354-364.

[3] V.M. Nguyen, S.B. Riffat, P.S. Doherty, Development of a solar-powered passive ejector cooling system, Appl. Therm. Eng. 21 (2001) 157-168.

[4] P. Srisastra, S. Aphornratana, T. Sriveerakul, Development of a circulating system for a jet refrigeration cycle, Int. J. Refrigeration 31 (2008) 921-929.

[5] B.J. Huang, S.S. Hu, S.H. Lee, Development of an ejector cooling system with thermal pumping effect, Int. J. Refrigeration 29 (2006) 476-484

[6] M. Sokolov, D. Hershgal, Enhanced ejector refrigeration cycles powered by low grade heat. Part 1. Systems characterization, Int. J. Refrigeration 12 (1990) 351-356.

[7] M. Sokolov, D. Hershgal, Enhanced ejector refrigeration cycles powered by low grade heat. Part 2. Design procedures, Int. J. Refrigeration 12 (1990) 357-363.

[8] M. Sokolov, D. Hershgal, Enhanced ejector refrigeration cycles powered by low grade heat. Part 3. Experimental results, Int. J. Refrigeration 14 (1991) 24-31.

[9] A. Arbel, M. Sokolov, Revisiting solar-powered ejector air conditioner - the greener the better, Solar Energy 77 (2004) 57-66.

[10] D.W. Sun, Solar powered combined ejector-vapour compression cycle for air conditioning and refrigeration, Energy Convers. Mngmt. 38 (1997) 479-491.

[11] D.W. Sun, Evaluation of a combined ejector-vapour compression refrigeration, Int. J. Energy 22 (1998) 333-342.

[12] Jin Hua Wang, J.H. Wu, S.S. Hu, B.J. Huang, Performance of ejector cooling system with thermal pumping effect using R141b and R365mfc, Appl. Therm. Eng. 29 (2009) 1904-1912.

[13] B.J. Huang, J.H. Wu, H.Y. Hsu, J.H. Wang, Development of hybrid solar-assisted cooling/heating system, Energy Convers. Manage. 51 (2010) 1643-1650.

[14] B.J. Huang, C.W. Yen, J.H. Liu, J.H. Wu, H.Y. Hsu, V.O. Petrenko, J.M. Chang, C.W. Lu. Performance test of solar-assisted ejector cooling system. Int. J. Refrigeration, submitted for publication.

[15] B.J. Huang, C.B. Jiang, F.L. Hu, Ejector performance characteristics and design analysis of jet refrigeration systems, Trans. ASME J. Eng. Gas Turbines Power 107 (1985) 792-802. 